\title{
ASSESSMENT OF MALNUTRITION IN CHILDREN WITH CANCER DURING ONCOLOGICAL TREATMENT
}

\author{
STAN ODŻYWIENIA U DZIECI LECZONYCH ONKOLOGICZNIE
}

\author{
${ }^{1}$ Department of Pediatrics, Oncology and Hematology, ${ }^{2}$ Department of Pediatric Nursery, \\ ${ }^{3}$ Department of Pharmacology and Therapeutics \\ Collegium Medicum in Bydgoszcz, Nicolaus Copernicus University
}

S u m m a r y

A im of the study. Assessment of malnutrition status in children with cancer during oncological treatment.

Material and methods. 62 children aged from 0 to 18 years were included. Anthropometric and biochemical parameters were measured: weight (W), height $(\mathrm{H})$, middle arm circumference (MAC), triceps skinfold thickness (TSFT), serum albumin. Middle arm muscle circumference (MAMC) was calculated. These variables were interpreted in accordance with Polish population percentiles charts and analyzed according AHOPCA 2004 Report. Adequately nourished- all criteria must be fulfilled: ideal body weight (IBW) $\geq 90$ th percentile(ile), albumin $>3,5 \mathrm{~g} / \mathrm{dL}$, weight loss $<5 \%$; TSFT and MAC both above the 10th ile. Inadequately nourished: at least one of these criteria must be fulfilled without isolated hipoalbuminemia; Depleted: IBW 60-89\%, albumin 3,2-
$3,5 \mathrm{~g} / \mathrm{dL}$, weight loss $5-10 \%$,TSFT and/or MAC between the 5-10th ile; Severely depleted: IBW $<60 \%$, albumin $<3,2 \mathrm{~g} / \mathrm{dL}$, weight loss $>10 \%$, TSFT and/or MAC less than 5th ile.

$\mathrm{Results}$. The prevalence of malnutrition at diagnosis ranged from several to nearly $50 \%$ children, depending upon the measurement used - in $22.6 \%$ of children by $\mathrm{W}$, in $17.7 \%$ by $\mathrm{H}$, in $19.4 \%$ by $\mathrm{W} / \mathrm{H}$ ratio, in $21.0 \%$ by TSFT, in $32,3 \%$ by MAC, in $46,8 \%$ by MAMC. Hipoalbuminemia was noted in $29,0 \%$ of children. Weight loss $>5 \%$ was detected in $29 \%$ of children, in $11 \%$ it was higher than $10 \%$. At diagnosis about $37 \%$ of children were adequately nourished, $39 \%$ were depleted and $24 \%$ severely depleted. Finally, $66 \%$ of children were adequately nourished, but $14.5 \%$ had severe malnutrition in the final examination.

Con clusions. Arm anthropometry is very useful for malnutrition detection and nutritional intervention.

\section{Streszczenie}

Cel pracy. Ocena stanu odżywienia u dzieci leczonych onkologicznie z powodu choroby nowotworowej.

Materiał i metody. do badania włączono 62 dzieci w wieku od 0 do 18 lat. Oceniano parametry antropometryczne: waga (W), wysokość (H), obwód środkowej części ramienia (MAC), grubości fałdu skórnego nad mięśniem trójgłowym ramienia (TSFT) oraz oznaczono stężenie albuminy w surowicy. Obliczano wskaźnik MAMC. Uzyskane wyniki były interpretowane zgodnie z polskimi tabelami percentylowymi ludności i analizowane zgodnie $\mathrm{z}$ raportem AHOPCA 2004. Prawidłowe odżywienie-spełnione wszystkie kryteria: idealna waga ciała (IBW) $\geq 90$ th percentyla (ile), albumina $>3,5 \mathrm{~g} / \mathrm{dl}$, utrata masy ciała $<5 \%$; TSFT oraz MAC obu powyżej 10. Ile. Niedostateczne odżywienie: co najmniej jedno z tych kryteriów musi być spełnione bez jednoczesnej hipoalbuminemii; niedożywienie: IBW 60-89\%, albumina 3,2-3,5 g/dl, utrata masy ciała o 5$10 \%$, TSFT i/lub MAC pomiędzy 5-10th Ile; ciężkie niedożywienie: ICC $<60 \%$, stężenie albumin $<3,2 \mathrm{~g} / \mathrm{dl}$, utrata masy ciała $>10 \%$, TSFT i / lub MAC mniej niż 5 th Ile.

W y n i ki. Częstość niedożywienia podczas diagnostyki wahała się w zakresie od kilku do prawie $50 \%$ dzieci, w zależności od zastosowanej metody- 22,6\% dzieci ocena $\mathrm{W}$, w 17,7\% w H w 19,4\% stosunek W / H , w 21,0\% wg TSFT, w 32,3\% wg MAC, w 46,8\% wg MAMC. Hipoalbuminemię stwierdzono u $29,0 \%$ dzieci. Utrata masy ciała $>5 \%$ stwierdzono u $29 \%$ dzieci, w $11 \%$ był wyższy niż $10 \%$. Podczas diagnostyki ok $37 \%$ dzieci było odpowiednio odżywione, niedożywienie stwierdzono u $39 \%$, a ciężkie niedożywienie u $24 \%$. Ostatecznie $66 \%$ dzieci było 
odpowiednio odżywione, a u 14,5\% występowało poważne niedożywienie w ostatnim badaniu.
Wnioski. Badanie antropometryczne jest bardzo przydatne do wykrywania niedożywienia i umożliwia szybką i adekwatną interwencję żywieniową.

Key words: nutritional assessment, cancer in children

Stowa kluczowe: badanie stanu odżywienia, choroba nowotworowa u dzieci

\section{INTRODUCTION}

Malnutrition in cancer disease is a complex problem caused by the prolonged, lower dietary intakes, chronic disease and side effects of oncological treatment. The occurrence and the increase of nutrition disorders depend on the type, location and stage of cancer and on the applied therapy. According to the Polish data, malnutrition appears in $8-32 \%$ of children with newly diagnosed cancer, and in $40 \%$ of children in progression cachexia is observed [1].

A lot of authors write about the correlation between the nutrition status and the results of oncological treatment, which depend on the infectious complications and number of recurrences. Clinical researches show less frequent delays in treatment and doses reduction, also better therapy results in case of proper nutrition [2-9]. That is why one of the priorities in oncological treatment is not to allow the malnutrition happen, especially protein deficiency.

A great deal of clinical trials was done on children in the developing countries, where the problem of malnutrition is observed not only in chronically ill children. In 2005 AHOPCA (Asociacion de HematoOncologia Pediatrica de Centro America) published their guidelines for the assessment of nutritional status in children with cancer. To estimate the nutritional status they took into account the data such as weight loss, some simple anthropometric measures, like triceps skinfold thickness (TSFT) and middle arm circumference (MAC), and albumins level, which is the most popular biochemical marker of malnutrition. An actual body weight was shown as \% Ideal Body Weight (\% IBW) plotted on the same centile for age, gender and height [10]. It is essential for the practical reason to combine the results of these measurements with nutrition support guidelines [11].

The criteria shown above are consistent with the European Society of Pediatric Gastroenterology, Hepatology and Nutrition (ESPGHAN) guidelines from 2012, which also takes into consideration the weight loss and triceps skinfold thickness in the assessment of the nutrition status and nutrition support [6].

\section{AIM OF STUDY}

The aim of the study was the assessment of nutritional status in children with cancer during oncological treatment with especially malnutrition cases diagnosed in terms of wide range of anthropological indexes and albumins level, and their utility in classification for nutrition support.

\section{MATERIAL AND METHODS}

62 children with newly diagnosed cancer disease were included in the study, 31 girls and 31 boys, aged from 0 to 18 , treated in 2008-2010. In this group, 23 children underwent treatment for acute lymphoblastic leukemia, 14 due to lymphoma, and 25 due to solid tumors.

In order to make the assessment of the nutritional status there were anthropometric parameters measured, such as body weight and height, middle arm circumference, triceps skinfold thickness. On the basis of the last two parameters there was the middle arm muscles circumference calculated, which shows indirectly lean body mass, as follows: $\mathrm{MAMC}=\mathrm{MAC}-$ (TSFT x 0.314). Albumin level was measured as the biochemical marker of malnutrition. These parameters were measured three times: at diagnosis, in the middle of the treatment and after the intensive chemotherapy. The results were interpreted according to the criteria of Nutritional Status in Children with Cancer: A Report From the AHOPCA 2004 [10].

Table I. Criteria of nutritional status in children with cancer according to: A Report From the AHOPCA 2004

\begin{tabular}{|l|c|c|c|}
\hline \multicolumn{1}{|c|}{ parameter } & $\begin{array}{c}\text { adequately } \\
\text { nourished }\end{array}$ & $\begin{array}{c}\text { inadequately } \\
\text { nourished- } \\
\text { depleted }\end{array}$ & $\begin{array}{c}\text { inadequately } \\
\text { nourished- } \\
\text { severely } \\
\text { depleted }\end{array}$ \\
\hline$\%$ ideal body mass & $\geq 90$ & $60-89$ & $<60$ \\
\hline albumin [g/dl] & $>3.5$ & $3.2-3.5$ & $<3.2$ \\
\hline weight loss [\%] & $<5$ & $5-10$ & $>10$ \\
\hline $\begin{array}{l}\text { triceps skinfold } \\
\text { thickness } \\
\text { (percentile) }\end{array}$ & $>10$ & $5-10$ & $<5$ \\
\hline $\begin{array}{l}\text { middle arm } \\
\text { circumference } \\
\text { (percentile) }\end{array}$ & $>10$ & $5-10$ & $<5$ \\
\hline
\end{tabular}


The patients were diagnosed as adequately nourished or inadequately nourished within two groups: depleted or severe depleted. A patient had to fulfilled all the criteria to be defined as adequately nourished. Inadequately nourished group consisted of patients with at least one of the criteria except isolated hypoalbuminemia. Classification of a patient to the severely malnourished group should be connected with the nutrition intervention.

\section{RESULTS}

The number of patients with anthropometric and biochemical criteria under 10 percentile or below normal range at diagnosis, during and after the oncological treatment are presented in table II. observed the deterioration of nutrition and $37 \%$ of our patients did not change the nutrition status, according to the criteria used.

Table III. Classification of nutritional status in children with cancer according to: A Report From the AHOPCA 2004

\begin{tabular}{|c|c|c|c|c|}
\hline $\begin{array}{c}\text { number } \\
\text { of } \\
\text { patients }\end{array}$ & $\begin{array}{c}\text { order of } \\
\text { assessment }\end{array}$ & $\begin{array}{c}\text { adequately } \\
\text { nourished } \\
\mathbf{N}(\%)\end{array}$ & $\begin{array}{c}\text { inadequately } \\
\text { nourished- } \\
\text { depleted } \\
\mathbf{N}(\%)\end{array}$ & $\begin{array}{c}\text { inadequately } \\
\text { nourished- } \\
\text { severely depleted } \\
\mathbf{N}(\%)\end{array}$ \\
\hline 62 & $\begin{array}{c}\text { at } \\
\text { diagnosis }\end{array}$ & 37.1 & 38.7 & 24.2 \\
\hline 62 & $\begin{array}{c}\text { during } \\
\text { treatment }\end{array}$ & 43.5 & 35.5 & 21.0 \\
\hline 62 & $\begin{array}{c}\text { after } \\
\text { treatment }\end{array}$ & 66.1 & 19.4 & 14.5 \\
\hline
\end{tabular}

Table II. The number of patients with anthropometric and biochemical criteria under 10 centile or below normal range

\begin{tabular}{|c|c|c|c|c|c|c|c|c|}
\hline $\begin{array}{c}\text { number } \\
\text { of patients }\end{array}$ & $\begin{array}{c}\text { order } \\
\text { of assessment }\end{array}$ & $\begin{array}{l}\text { weight } \\
\text { for age } \\
\mathrm{N}(\%)\end{array}$ & $\begin{array}{l}\text { height } \\
\text { for age } \\
\mathrm{N}(\%)\end{array}$ & $\begin{array}{l}\text { weight for } \\
\text { height } \\
\mathrm{N}(\%)\end{array}$ & $\begin{array}{c}\text { middle arm } \\
\text { circumference } \\
\mathbf{N}(\%)\end{array}$ & \begin{tabular}{|c|} 
triceps skinfold \\
thickness \\
N $(\%)$
\end{tabular} & $\begin{array}{c}\text { middle arm muscle } \\
\text { circumference } \\
\text { N }(\%)\end{array}$ & $\begin{array}{c}\text { albumin } \\
<3,5 \mathrm{~g} / \mathrm{dL} \\
\mathrm{N}(\%)\end{array}$ \\
\hline 62 & at diagnosis & $\begin{array}{c}14 \\
22.6 \%\end{array}$ & $\begin{array}{c}11 \\
17.7 \%\end{array}$ & $\begin{array}{c}12 \\
19.4 \%\end{array}$ & $\begin{array}{c}20 \\
32.3 \%\end{array}$ & \begin{tabular}{|c|}
13 \\
$20.9 \%$
\end{tabular} & $\begin{array}{c}29 \\
46.8 \%\end{array}$ & $\begin{array}{c}18 \\
29.0 \%\end{array}$ \\
\hline 62 & $\begin{array}{c}\text { during } \\
\text { treatment }\end{array}$ & $\begin{array}{c}12 \\
19.4 \%\end{array}$ & $\begin{array}{c}14 \\
22.6 \%\end{array}$ & $\begin{array}{c}16 \\
25.8 \%\end{array}$ & $\begin{array}{c}17 \\
27.4 \%\end{array}$ & $\begin{array}{c}11 \\
17.7 \%\end{array}$ & $\begin{array}{c}27 \\
43.6 \% \\
\end{array}$ & $\begin{array}{c}7 \\
11.3 \%\end{array}$ \\
\hline 62 & $\begin{array}{c}\text { after } \\
\text { treatment }\end{array}$ & $\begin{array}{c}11 \\
17.7 \%\end{array}$ & $\begin{array}{c}15 \\
24.2 \%\end{array}$ & $\begin{array}{c}12 \\
19.4 \%\end{array}$ & $\begin{array}{c}9 \\
14.5 \%\end{array}$ & $\begin{array}{c}8 \\
12.9 \%\end{array}$ & $\begin{array}{c}24 \\
38.7 \%\end{array}$ & $\begin{array}{c}7 \\
11.3 \%\end{array}$ \\
\hline
\end{tabular}

At diagnosis, depending on the index used there were from $17.7 \%$ to $46.7 \%$ children under 10 percentile. Body weight deficiency was observed in $22.6 \%$ of children, $17.7 \%$ of patients were below the body height normal range. Weight for height ratio was $<10$ percentiles in $19.3 \%$ of children. Additional anthropometric measurements showed the decreased values of triceps skinfold thickness in $20,9 \%$, middle arm circumference in $32.3 \%$, middle arm muscles circumference in $46.8 \%$ of the children. The decreased level of albumins was seen in $29 \%$ of children. $29 \%$ of children showed the body mass loss more than $5 \%$ in the last month, among them $11 \%$ showed over $10 \%$ body mass loss.

At diagnosis $37 \%$ of children were classified as adequately nourished according to these criteria, 39\% of children were depleted and $24 \%$ were severely depleted. During the treatment the number of adequately nourished children increased and in the group of depleted and severely depleted it decreased. The assessment after the intensive chemotherapy showed that the number of adequately nourished children increased again up to $66 \%$. Our survey found that during the oncological treatment $48.4 \%$ of children improved their nutrition status, in $14.5 \%$ cases we
The assessment of the nutritional status according to AHOPCA 2004 Report based on history taking about body weight loss and on anthropometric and biochemical measurements showed severe malnutrition in $24.2 \%$ of children before the treatment and in $14.5 \%$ in the final one.

\section{DISCUSSION}

Basing our study on the criteria from Meeting Report AHOPCA 2004 we found the improvement of nutritional status in children with cancer during oncological therapy. In the examination after the intensive chemotherapy the number of children adequately nourished increased, and the number of malnourished children decreased, however it was still $33.8 \%$. When comparing this qualification method to the single anthropometric and biochemical rates, the most similar was the middle arm muscles circumference (MAMC) value, which in the assessment after the treatment was below the normal rate in $38.7 \%$ of the children [5].

The highest percentage of children with malnutrition was detected by such additional anthropometric measurement as middle arm muscles circumference (MAMC)- $46.7 \%$ at the diagnosis. The 
number of children with arm circumference and fat skinfolds below 10 percentile decreased during the oncological treatment with the lowest percentage at the assessment after the intensive chemotherapy.

Weight loss is the important sign of malnutrition. It is common in clinical studies and oncological diagnosis. In the ESPGHAN report from 2005 the inhibition of body weight increasing followed by weight loss was acknowledged the earliest malnutrition symptom [12]. Weight loss is also important criteria for nutrition intervention. According to the MEETING REPORT AHOPCA 2004 weight loss of over 5\% during the previous month is the criteria for malnutrition even if the anthropometric measures are within norm. In our own study weight loss was observed in $29 \%$ of children at diagnosis, which means one third of children were inadequately nourished before the oncological treatment $[6,12]$.

\section{CONCLUSIONS}

1. The results of the study confirm that normal body weight does not mean the correct body composition and cannot be the only criteria for adequate nutrition.

2. Weight and height measurements underestimate the protein-energy malnutrition in children with cancer disease. In our study the analysis of the correlation of different methods showed the usefulness of additional anthropometric measurements, such as middle arm circumference, triceps skinfold thickness, middle arm muscles circumference. They are more efficient in early malnutrition detection than body weight and height indices. Serum protein measurements (albumin) are less sensitive than muscles protein estimation by anthropometric measurements in protein malnutrition detection.

3. The combined estimation of nutritional status undertaking weight loss, fat and lean body mass measurements and albumin level help in early detection of nutrition disorders and qualifying patients for nutrition support. The oncological therapy may temporarily influence the nutrition status, growing the risk of malnutrition, but when the remission is achieved, the nutrition status is improved.

\section{REFERENCES}

1. Bautembach-Minkowska J, Balcerska A: Zaburzenia odżywienia i leczenie żywieniowe $w$ chorobie nowotworowej u dzieci. W: Chybicka A, SawiczBirkowska K. red. Onkologia i Hematologia Dziecięca.
Wydawnictwo Lekarskie PZWL,Warszawa 2008,1074 1087.

2. Correia MI, Waitzberg DL: The impact of malnutrition on morbidity, mortality, length of hospital stay and costs evaluated through a multivariate model analysis. Clinical Nutrition 2003, 22: 235-239.

3. Lange BJ, Gerbing RB, Feusner J, Skolnik J, Sacks N, Smith FO, Alonzo TA: Mortality in overweight and underweight children with acute myeloid leukemia. JAMA 2005, 293: 203-211.

4. Rogers PC, Melnick SJ, Ladas EJ, Halton J, Baillargeon J, Sacks N: Children's Oncology Group (COG) Nutrition Committee. Pediatric Blood \& Cancer 2008, 50: 447 450.

5. Sala A, Pencharz P, Barr RD: Children, cancer, and nutrition - A dynamic triangle in review. Cancer 2004, 100: 677-687.

6. Sala A, Rossi E, Antillon F, Molina AL, de Maselli T, Bonilla M, Hemandez A, Ortiz R, Pacheco C, Nieves R, Navarette M, Barrantes M, Pencharz P, Vaisecchi MG, Barr R: Nutritional status at diagnosis is related to clinical outcomes in children and adolescents with cancer :a perspective from Central America. European Journal of Cancer 2012, 48,243-252.

7. Tazi I, Hidane Z, Zafad S, Harif M, Benchekroun S, Ribeiro R: Nutritional Status at Diagnosis of Children with Malignancies in Casablanca. Pediatric Blood \& Cancer 2008, 51: 495-498.

8. Grześk G, El-Essa A, Kubica A, Grześk E, Kubica J, Koziński M: Rosuwastatyna w prewencji pierwotnej schorzeń układu sercowo-naczyniowego. Folia Cardiol Excerpta 2010, 5: 141-144.

9. Tejza B, Kurylak A, Grześk E, Grześk G: The evaluation of nutritional status disorders as a state of overweight and hyperlipidemia in children with cancer. Med Biol Sci 2014, 28: 57-61.

10. Sala A, Antillon F, Pencharz P, Barr R: MEETING REPORT. Nutritional status in children with cancer: a report from the AHOPCA workshop held in Guatemala City, August 31-September 5, 2004. Pediatric Blood \& Cancer 2005,45: 230-236.

11. Co-Reyes E, Li R, Huh W, Chandra J: Malnutrition and Obesity in Pediatric Oncology Patients: Causes, Consequences, and Interventions. Pediatric Blood \& Cancer 2012, 59: 1160-1167.

12. Agostoni C, Axelsson I, Colomb V, Goulet O, Koletzko B, Michaelsen KF, Puntis JWL, Rigo J, Shamir R, Szajewska H, Turck D : The Need for Nutrition Support Teams in Pediatric Units: A Commentary by the ESPGHAN Committee on Nutrition. Journal of Pediatric Gastroenterology and Nutrition 2005, 41,8-11.

Address for correspondence:

Department of Pediatric, Oncology and Hematology

Nicolaus Copernicus University Collegium Medicum

in Bydgoszcz

ul. M. Skłodowskiej-Curie 9

85-094 Bydgoszcz

Received: 12.12.2014

Accepted for publication: 24.03.2015 